\title{
Guanylate cyclase activity in normal and diseased human muscle
}

\author{
CESARE CER R I, N I C O L A A N A L, A N D \\ L O D O I C O FR A T T O LA
}

From the Neurological Department, University of Milan, Milan, Italy

SUM MARY Guanylate cyclase activity has been studied in muscle of normal subjects and of patients suffering from muscular and neuromuscular diseases. In normal tissue a guanylate cyclase activity was found in both soluble and particulate fractions of homogenate. We found also that the kinetic analysis of the enzyme of soluble differed from that of particulate fraction. A decrease of guanylate cyclase activity in crude homogenate was observed in muscular dystrophies, in neuromuscular atrophies, and in inflammatory forms of muscle disease.

Although cyclic nucleotides are recognised as regulators of many physiological and pathological events, the mechanisms by which they act are still unclear.

In skeletal muscle cyclic nucleotides are involved in neurotrophic function, in synaptic transmission, in contraction, and in myogenesis (Goldberg et al., 1973; Takamori et al., 1973; Carlsen, 1975; Epstein et al., 1975; Kebabian et al., 1975; Stone et al., 1975; Standaert et al., 1976).

In human muscular pathological conditions, previous findings indicate that the activity of adenylate cyclase and of cyclic nucleotides phosphodiesterase are frequently altered (Canal and Frattola, 1974; Mawatari et al., 1974; Susheela et al., 1975; Canal et al., 1977).

Guanylate cyclase (EC.4.6.1.2), the enzyme that catalyses the conversion of guanosine triphosphate (GTP) to guanosine-3', 5'-monophosphate (cGMP), was present in particulate and soluble fractions of animal heart and skeletal muscle where it displayed different distribution and kinetic properties, and probably different physiological roles (Kimura and Murad, 1974; Sulahke et al., 1976).

In denervated skeletal rabbit muscle the activity of this enzyme is increased in all tissue fractions; in contrast, in the same muscle the adenylate cyclase activity is greatly decreased (Novom and

This study was supported by grant from the Consiglio Nazionale delle Ricerche of Italy.

Address for reprint requests: Professor L. Frattola, Department of Neurology, Pad. Ponti-Policlinico, Via Francesco Sforza 35, 20122 Milano, Italy.

Accepted 30 March 1978
Lewinstein, 1977). These observations, and the lack of information on guanylate cyclase studies in the human muscle, have led us to investigate this enzyme in the muscle of normal subjects and patients suffering from different muscular diseases.

\section{Material and methods}

HUMAN MATERIAL

Muscle samples were taken from deltoid or quadriceps muscles under local anaesthesia with $10 \mathrm{ml}$ of procaine $2 \%$, without adrenaline. Care was taken not to infiltrate the muscular tissue. The diagnosis was based on clinical criteria, electrophysiological, serological, and histochemical tests.

The group of neurogenic atrophies included spinal atrophies (juvenile forms), amyotrophic lateral sclerosis and Charcot-Marie-Tooth disease; the group of muscular atrophy included the sexlinked types (Duchenne's and Becker's forms). Control muscle samples were taken under local anaesthesia as the first procedure during orthopaedic operations from deltoid or quadriceps muscles of patients with no evidence of muscular disease.

All subjects had been kept without any pharmacological treatment for at least five days.

CHEMICAL MATERIAL

Guanosine 5'-triphosphate sodium salt (GTP), creatine phosphate sodium salt, creatinekinase (skeletal rabbit muscle), acetylcholine chloride (ACh), and Tris (tris-hydroxymethyl-aminomethane) were purchased from Boehringer GmB. All 
other reagents were of analytical grade. The radioimmunoassay kits were purchased from New England Nuclear Chemicals GmB.

\section{TISSUE PREPARATION}

All procedures for the enzyme preparation were carried out at $4^{\circ} \mathrm{C}$. The tissue samples were homogenised in six volumes of $0.25 \mathrm{M}$ sucrose containing $10 \mathrm{mmol}$ Tris- $\mathrm{HCl}$ buffer $\mathrm{pH} 8.0$ (at room temperature), using a Potter-Elvehjem homogeniser with Teflon pestle. The homogenate was centrifuged for $10 \mathrm{~min}$ at $1500 \mathrm{~g}$ (av) to remove debris, and the supernatant thus obtained was employed as crude homogenate preparation. Aliquots of this homogenate preparation were centrifuged at $40000 \mathrm{~g}$ (av) for $90 \mathrm{~min}$. While the supernatant was used as soluble (or supernatant) fraction, the resulting pellets were suspended in a volume of homogenising buffer equal to that of the original homogenate and used as the particulate fraction. Because of the small tissue samples, in pathological conditions the subcellular distribution of the enzyme was not studied, and in pathological tissues the guanylate cyclase activity was investigated only in crude homogenates.

\section{ASSAY OF GUANYLATE CYCLASE}

The method of Kimura et al. (1975) was used to determine guanylate cyclase activity. The standard incubation mixture, in a final volume of $100 \mu \mathrm{l}$, contained $50 \mathrm{mmol} / 1$ Tris-HC1 buffer $(\mathrm{pH} 7.6$ at $37^{\circ} \mathrm{C}$ ), $10 \mathrm{mmol} / 1$ theophylline, $2 \mathrm{mmol} / 1 \mathrm{MnCl}_{2}$, $15 \mathrm{mmol} / 1$ creatine phosphate, $20 \mu \mathrm{g}$ of creatine kinase and $40 \mu 1$ of enzyme preparation.

Guanylate cyclase activity was started by adding $2 \mathrm{mmol} / 1$ GTP to the reaction mixture (preincubated for $10 \mathrm{~min}$ at $37^{\circ} \mathrm{C}$ ), and it was run at $37^{\circ} \mathrm{C}$ for $15 \mathrm{~min}$. To prevent nonenzymatic formation of cGMP the reaction was stopped by adding $0.9 \mathrm{ml}$ of $50 \mathrm{mmol} / 1$ sodium acetate buffer (pH 4.0) and then heated for $3 \mathrm{~min}$ at $90^{\circ} \mathrm{C}$. Samples incubated with boiled enzymes were used as controls.

Reactions were performed in triplicate. The heated incubation extracts were centrifuged at $1.500 \mathrm{~g}$ for $15 \mathrm{~min}$ and aliquots of $100 \mu \mathrm{l}$ were assayed for cGMP using the radioimmunoassay of Steiner et al. (1972). Noncollagenous protein concentration was determined according to the method of Lowry et al. (1951) after alkali digestion by the procedure of Lillienthal et al. (1950).

The kinetic analysis was carried out only in the soluble and particulate fractions. Enzyme activity data were plotted in the presence of various concentrations of substrate according to the procedure of Lineweaver and Burk (1934).
In comparison between normal and pathological groups, the statistical significance of the results was determined by Student's two-tailed $t$ test.

\section{Results}

Results of the kinetic analysis for guanylate cyclase in normal skeletal muscle are shown in the Figure. For the soluble fraction the apparent $K_{\mathrm{m}}$ of the enzyme is about $132 \mu \mathrm{M}$, while the Michaelis constant for the particulate fraction is about $31 \mu \mathrm{M}$.

The Figure shows that some difference can also be observed in the Vmax of the enzyme present in the two subcellular preparations, that of the soluble being slightly higher than that of the particulate fraction.

Table 1 shows the data on enzyme measurement in the homogenate, in the soluble and in particulate fractions of normal skeletal muscle. In the homogenate the cGMP formed by $1 \mathrm{mg}$ of protein in $15 \mathrm{~min}$ was $82.5 \pm 6.3 \mathrm{pmol}$, in the soluble and particulate it was $39.4 \pm 10.2 \mathrm{pmol}$ and $161.4 \pm$ 55.1 pmol respectively.

In normal subjects no difference in guanylate cyclase activity was observed as far as age, sex, $\frac{\circ}{\mathbb{D}}$ and muscle used (deltoid or quadriceps) were concerned.

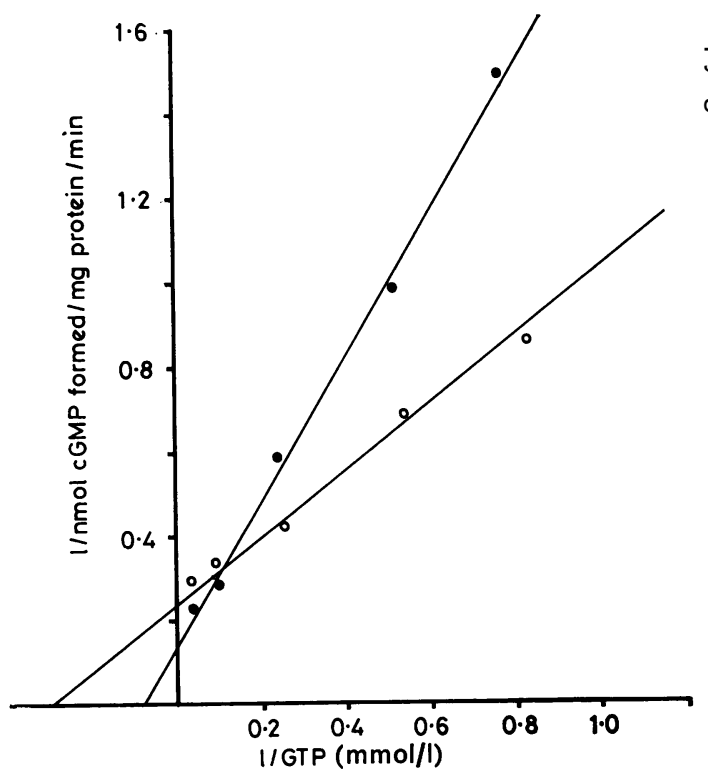

Figure Double reciprocal plot of cGMP formation as a function of cGMP concentration in a soluble (•) and particulate $\bigcirc)$ fraction of normal human skeletal muscle. The conditions of the assay are described in Material and Methods section. Each point represents the mean of four determinations. 
Table 1 Guanylate cyclase activity in normal skeletal muscle

\begin{tabular}{llll}
\hline Reaction mixture & $\begin{array}{l}\text { Crude } \\
\text { homogenate }\end{array}$ & Supernatant & Particulate \\
\hline Without additions (10) & $82.5 \pm 6.3$ & $39.2 \pm 10.2$ & $161.4 \pm 55.2$ \\
With 25 $\mu$ mol/1 ACh (5) & $89.1 \pm 5.8$ & $43.4 \pm 11.2$ & $152.3 \pm 56.1$
\end{tabular}

Data represent the mean \pm SD; values expressed as pmol of cGMP formed/15 minutes/milligram of noncollagenous protein; number of subjects in brackets.

In our experimental conditions the cGMP formed was linear with respect to protein concentration (up to $200 \mu \mathrm{g}$ ) and incubation time (up to $30 \mathrm{~min}$ ).

We have measured guanylate cyclase activity in presence of different concentrations of $\mathrm{Mn}^{++}$ $(0.5,1,2,3$, and $4 \mathrm{mmol} / \mathrm{l})$. The maximal response was observed in the presence of $2 \mathrm{mmol} / 1 \mathrm{MnCl}_{2}$. No further increased activity was observed with $3 \mathrm{mmol} / 1$ of $\mathrm{MnCl}_{2}$, while at $4 \mathrm{mmol} / 1$ the activity was slightly decreased. The influence of $\mathrm{Mn}^{++}$in activating the enzyme was similar for soluble and particulate fraction.

Cholinergic agents are not able to stimulate the guanylate cyclase. In fact, Table 1 shows that the addition of $25 \mu \mathrm{mol} / 1 \mathrm{ACh}$ to the incubation mixture does not increase the cGMP formation.

As indicated in Table 2, in comparison with normal tissue, we found a significant decrease of enzyme activity in the homogenate of muscular dystrophies, neurogenic atrophies, and polymyositis, while in myotonic dystrophy and in myasthenia gravis the level of guanylate cyclase is in the normal range.

The results obtained in the muscle of patients suffering from mitochondrial myopathy are of particular interest: although only two cases were studied, both showed a remarkably low enzymatic activity.

Table 2 Guanylate cyclase activity in homogenates of human skeletal muscle

\begin{tabular}{ll}
\hline Tissue & $\begin{array}{l}\text { Guanylate cyclase activity } \\
\text { (pMcGMPformed/mg } \\
\text { protein/15 min) }\end{array}$ \\
\hline Normal adult (10) & $82.2 \pm 8.4$ \\
Normal child (5) & $84.1 \pm 9.1$ \\
Muscular dystrophy (6) & $29.2 \pm 5.7^{*}$ \\
Mitochondrial myopathy (2) & $3.0 \pm 3.3$ \\
Neurogenic atrophy (8) & $33.8 \pm 7.2^{*}$ \\
Polymyositis (5) & $52.5 \pm 9.8$ \\
Myasthenia gravis (4) & $78.6 \pm 5.3$ \\
Definite carrier of Duchenne & $85.6 \pm 9.7$ \\
muscular dystrophy (4) &
\end{tabular}

Each value represents the mean $\pm S D$; number of subjects for each group in brackets; ${ }^{*} \mathbf{P}<0.05$ (versus normals), the other differences are not significant.

\section{Discussion}

The results of the present study demonstrate the presence of a guanylate cyclase activity in human skeletal muscle. The enzyme is present in both soluble and particulate fraction of the homogenate, where it shows different distribution and kinetic properties. In normal tissue the enzymatic activity of the particulate fraction is higher than that of the soluble, while the $K_{\mathrm{m}}$ is lower in particulate than in soluble fraction.

Our findings that optimal activity of enzyme require the presence of low concentration of $\mathrm{Mn}^{++}(2 \mathrm{mmol} / 1$ in our experimental conditions), are in agreement with those observed in the heart or skeletal muscle of animals (Kimura and Murad, 1974; Sulahke et al., 1977).

Several reports suggest that cholinergic agents also stimulate the guanylate cyclase in broken cell preparations (Goldberg et al., 1973; De Rubertis and Craven, 1976). In our study the addition of acetylcholine to the incubation mixture did not increase the cGMP formation. The same conclusion has been published recently by Novom and Lewinstein (1977) in subcellular preparations of normal and denervated skeletal muscle of rabbits.

In the homogenate of some muscular diseases the regulation of guanylate cyclase system seems to be altered (Table 2). In particular we found a significant and similar decrease of enzyme activity both in myopathies and in neurogenic atrophies of muscle. These data could lead to the conclusion that in human muscular atrophies the change in guanylate cyclase activity is not related to the neurogenic or myogenic origin of the amyotrophy. On the other hand, it should be emphasised that the change of guanylate cyclase in human chronic neurogenic atrophies is in the opposite direction to that observed by Novom and Lewinstein (1977) in the skeletal muscle of rabbits after denervation, where the enzyme activity is "increased several times."

As the metabolic role and physiological significance of cGMP in skeletal muscle is not yet known, it is difficult to explain its alterations in pathological conditions. In an attempt to clarify the mechanisms for regulation of guanylate cyclase system in human skeletal muscle, we are carrying out a study of the subcellular distribution, kinetic properties, and pharmacological responsiveness of this enzyme in patients suffering from muscular or neuromuscular diseases. Our preliminary data regarding two cases of Duchenne's dystrophy indicate that guanylate cyclase activity is present mostly in the soluble fraction of the homogenate, while in neurogenic atrophies-one 
case of amyotrophic lateral sclerosis and two cases of spinal atrophies-the enzyme does not show significant changes in subcellular distribution.

We appreciate Miss Andreina Bordoni's helpful suggestions during the experiments.

\section{References}

Canal, N., and Frattola, L. (1974). Phosphodiesterase and adenylcyclase in normal and diseased muscle. In Recent Advances in Myology, pp. 273-276. Edited by W. G. Bradley, D. Gardner-Medwin, and J. N. Walton. Excerpta Medica: Amsterdam.

Canal, N., Cerri, C., Musch, B., and Frattola, L. (1977). Metabolism of cyclic nucleotides in healthy and diseased human muscle. Israel Journal of Medical Sciences, 13, 147-151.

Carlsen, R. C. (1975). The possible role of cyclic AMP in the neurotrophic control of skeletal muscle. Journal of Physiology, 247, 343-361.

De Rubertis, F. R., and Craven, P. A. (1976). Properties of the guanylate cyclase-guanosine $3^{\prime}-5^{\prime}$ monophosphate system in rat adrenal cortex. Journal of Biological Chemistry, 251, 4651-4658.

Epstein, C. J., Jimenez, de Asua, L., and Rozengurt, E. (1975). The role of cyclic AMP in myogenesis. Journal of Cellular Physiology, 86, 83-90.

Goldberg, N. D., O'Dea, N. F., and Hadden, M. R. (1973). Cyclic AMP. In Advances in Cyclic Nucleotide Research, Vol. 3, pp. 155-223. Edited by P. Greengard and G. A. Robison. Raven Press: New York.

Kebabian, J. W., Steiner, A. L., and Greengard, P. (1975). Muscarinic cholinergic regulation of cGMP in autonomic ganglia: possible role in synaptic transmission. Journal of Pharmacology and Experimental Therapeutics, 193, 474-488.

Kimura, H., Mittal, C. K., and Murad, F. (1975). Activation of guanylate cyclase from rat liver and other tissue by sodium azide. Journal of Biological Chemistry, 250, 8016-8022.

Kimura, H., and Murad, F. (1974). Evidence for two different forms of guanylate cyclase in rat heart. Journal of Biological Chemistry, 249, 6910-6916.
Lillienthal, J. L., Lierlor, K. L., and Folk, B. P. (1950). A reference base and system for analysis of muscle constituents. Journal of Biological Chemistry, 185, 501-509.

Lineweaver, H., and Burk, D. (1934). The determination of enzyme dissociation constants. Journal of American Chemistry Society, 56, 658-665.

Lowry, O. H., Rosebrough, N. J., Farr, A. L., and Randall, R. J. (1951). Protein measurement with the folin phenol reagent. Journal of Biological Chemistry, 193, 265-275.

Mawatari, S., Takagi, A., and Rowland, L. P. (1974). Adenyl cyclase in normal and pathological human muscle. Archives of Neurology (Chicago), 30, 96102.

Novom, S., and Lewinstein, C. (1977). Adenylate cyclase and guanylate cyclase of normal and denervated skeletal muscle. Neurology (Minneapolis), 27, 869-874.

Standaert, F. G., Dretchen, K. L., Skirboll, L. R., and Morgenroth, V. H. (1976). A role of cyclic nucleotides in neuromuscular transmission. Journal of Pharmacology and Experimental Therapeutics, 199, 553-564.

Steiner, A. L., Parker, C. V., and Kipnis, D. M. (1972). Radioimmunoassay for cyclic nucleotides. Journal of Biological Chemistry, 247, 1106-1113.

Stone, T. W., Taylor, D. A., and Bloom, F. E. (1975). Cyclic AMP and cyclic GMP may mediate opposite neuronal responses in the rat cerebral cortex. Science, 187, 845-847.

Sulahke, S. J., Leung, N. L., and Sulahke, P. V. (1977). Interactions of divalent cations and nucleotides with solubilised cardiac guanylate cyclase. Enzyme, 22, 141-144.

Sulahke, P. V., Sulahke, S. J., Leung, N. L., St. Louis, P. J., and Hickie, R. A. (1976). Guanylate cyclase subcellular distribution in cardiac muscle, skeletal muscle, cerebral cortex and liver. Biochemical Journal, 157, 705-712.

Susheela, A. K., Kaul, R. D., Sachdiva, K., and Singh, N. (1975). Adenylate cyclase activity in Duchenne dystrophic muscle. Journal of the Neurological Sciences, 24, 361-363.

Takamori, M., Ishii, N., and Mori, M. (1973). The role of cyclic AMP in neuromuscular transmission. Archives of Neurology (Chicago), 29, 420-424. 